\title{
SHORT REFLECTIONS ON THE EFFECTS OF DOMESTIC ADOPTIONS
}

\section{A. Drăghici}

\author{
Andreea Drăghici \\ Faculty of Law and Administration \\ University of Pitesti, Pitesti, Romania \\ *Correspondence: Andreea Draghici, Bld. Republicii, no. 71, Pitesti, Romania \\ E-mail: andidraghici@yahoo.com
}

\section{Abstract:}

The act of granting an adoption produces two main types of effects. The first type of effect creates a bond of filiation between the adopter and the adoptee, as well as family bonds between the adoptee and the adopter's relatives. The second type of effect erases the natural relation between the adoptee and the former parents but also between the adoptee's descendants on one side and the adoptee's natural relatives on the other.

Keywords: adoption, effects, the adoptee's name, the adoptee's residence, the adoptee's citizenship.

\section{Introduction}

It has been said that adoption is "one of the noblest expressions of generosity and altruism through which we prove our solidarity". Its purpose is to ensure "the patrimonial and non-patrimonial of children deprived of parental protection or any similar protection". Seen from a general perspective, adoption seems a "wonderful solution" for adoptive parents who are unable to establish a much-desired family of their own because of infertility or certain illnesses, as well as for natural parents who are faced with an unwanted problem ${ }^{3}$. At the same time, adoption is not a perfect solution, leading to complications and difficulties generated by both its specificity, but sometimes by incoherent legislation, which is unable to promote or guarantee the rights of the child.

\section{National and international adoption regulation}

On a national level, the lawmaker dedicates a full chapter of the Romanian Civil Code to adoptions, more precisely Chapter III, articles 451-482 from Title III "Kinship", Tome II "Family". These stipulations complete those of Law 273/2004 concerning the legal adoption regime $^{4}$ and governmental decision 350/2012 for the approval of Methodological rules for applying Law 273/2004 and of the organizational and functional rules of the Coordination Council for the Romanian Adoption Office.

At the same time, the Convention on the Rights of Children ${ }^{5}$ sanctions in article 20 the duty of the party states ${ }^{6}$, in accordance with their national legislation, to ensure alternative care to children who are temporarily or permanently deprived of a family environment or who cannot be left in this environment, if their best interests are to be protected, and have a right to care and special assistance from the state. Such care can include especially foster care,

\footnotetext{
${ }^{1}$ Emese Florian, Dreptul familiei, 3rd Edition, C.H. Beck Publishing House, Bucharest, 2010, p. 205.

${ }^{2}$ Al. Bacaci, Viorica Dumitrache, Codrufa Hageanu, Dreptul familiei, C.H. Beck Publishing House, Bucharest, 2012, p. 219.

${ }^{3}$ To see: D.M. Brodzinsky, M.D. Schechter, R. Marantz Henig, A fi adoptat. Căutarea de o viață a sinelui, taken from the book Being Adopted: The Lifelong Search for Self p. 1, available online at: www, adoptiiromania.ro.

${ }^{4}$ Republished in the Official Gazette of Romania, Part I, no. 259 from 19 April 2012.

${ }^{5}$ The International Convention on the Rights of the Child ratified by Romania through Law no. 18/1990, published in the Official Gazette of Romania, Part I, no. 314 from 13 June 2001.

${ }^{6}$ E. Ciongaru, Drept international privat, "Scrisul Romanesc" Publishing House, Craiova, 2011, p. 18.
} 
"kafalah" in Islamic law, adoption or if necessary placement in suitable institutions for the care of children. In order to choose one of these solutions it is necessary to take into account the need for a certain level of continuity of a child's education, ethnic, religious, cultural and linguistic background. Moreover, article 21 highlights the importance of the best interests of children in all proceedings related to their adoption.

In 2009, the UN Committee on the Rights of the Child recommended that Romania respect article 21 especially the best interests of children and therefore shorten all stages of the adoption process. Moreover, our country signed the revised European Convention on the Adoption of Children on 4 March 2009, passed in Strasbourg and ratified by Law 138/2011. These are some of the reasons leading to a new amendment of Law 273/2004.

De lege lata, adoption is defined by article 451 of the Romanian Civil Code as a "legal operation which creates a bond of filiation between adopter and adoptee, as well as bonds of kinship between adoptee and the adopter's relatives". In developing this definition, the lawmaker had thus taken into account the effects of adoption - the creation of a bond of filiation between adopter and adoptee, as well as legal family ties between the relatives of the adopter and the adoptee, from the date of the final judicial decision granting the adoption.

Beginning with the legal provisions mentioned above, we have defined adoption as the complex legal operation which creates a bond of filiation, under the law, between adopter and adoptee, and of lines of kinship between the adoptee and the adopter's relatives.

The Romanian Civil Code gives a general definition of adoption which is completed by the definitions of national and international adoptions found in Law 273/2004, in its republished form. These two concepts are explained for the first time in our legislation, thus putting an end to confusion between the two institutions, caused by the use of the legal residence as a differentiating criterion.

Given the integration of our country in the European Union, it has been noticed lately that in certain cases Romanian citizens have commenced adoption procedures domestically right after securing the right to reside permanently on the territory of another country, while keeping or reestablishing their residence in Romania, despite the fact that they were actually living on the territory of a foreign country. However, subsequent to end of the adoption process, these situations led to a number of difficulties in terms of their recognition by foreign states $^{7}$, including the child's status within that country. At the same time, when foreign nationals are granted permanent residence under the law in Romania, it subsumes the idea of domestic adoption - at the time when such adoptions are granted both adopter and adoptee should normally reside in Romania and therefore no such problem arises in cases of adoptions between a country of origin and a host country. It has been thus considered, given these considerations, that there is a necessity to regulate situations such domestic not international ${ }^{8}$ adoptions as soon as possible.

Likewise, the regular residence of the adopter or adoptive family and the child to be adopted has been used as a criterion for a better implementation of the Hague Convention' The concept of regular/habitual residence is increasingly being used in international legal documents. Moreover, our civil code also uses the concept of habitual residence, which required that stipulations in Law 273/2004 be correlated with those from the code. According to article 2 from the Law on the legal status of adoptions which has been republished, "an internal adoption is any adoption where both the adopter or adoptive family and the adoptee

\footnotetext{
${ }^{7}$ E. Ciongaru, Drept international privat, "Scrisul Romanesc" Publishing House, Craiova, 2011, pp. 25-27.

${ }^{8}$ In this regard, see: D. Buzducea, F. Lazar, Anca Bejenaru, V. Grigoraş, B. A. Panait, Ramona Popa, Strategii de comunicare despre adopție între parinți adoptivi şi copilul adoptat. Raport, "Romprint Paper SRL" Publishing House, Bucharest, 2013, p. 7.

${ }^{9}$ Convention on Protection of Children and Cooperation in international adoption, done concluded at the Hague on 29 May 1993 and ratified by Romania through Law 84/1994, published in Official Gazette of Romania, Part I, no. 298 from 21 October 1994, with subsequent amendments.
} 
are normally reside in Romania" and the international adoption is "any adoption in which case the adopter or adoptive family and the child to be adopted usually reside in different countries and, following the adoption, the child will have the same residence as the adopter".

\section{Overview of the effects of internal adoption}

Varied in nature, the effects of adoption appear only in the future, after the adoption has been granted by the court.

The adoption has legal effects starting on the date when the decision of the court to grant the adoption is permanent. According to article 74 of Law 273/2004 on the legal status of adoption, the court able to grant the adoption is that in the jurisdiction of which the adoptee resides. Based on the final ruling, the General Register Office shall issue a new certificate of birth in the name of the adoptee, in which the adoptive parents will be included in the box for natural parents. The old birth certificate will be kept and a reference to the new certificate is made on it.

In accordance with the Romanian Civil Code, the first and main consequence of the adoption is the creation of a bond of legal kinship. According to paragraph 1 of article 470 of the Civil Code, the act of adoption establishes a lineage between the adopter, and the adopter's family of course, and the child. Given that the current legislation covers only full adoptions, the bonds of kinship are also created between the descendants of the adoptee, on the one side, and the adopter and his/her relatives, on the other ${ }^{10}$.

The relatives resulted from the adoption have a mutual inheritance vocation mutual succession, just as the natural relatives in this case, following the rules established by the general legal principle of reciprocity vocation. While simultaneously opposed to and concurrent with the constitutive effect, adoptions also have an extinctive effect in the sense that natural kinship between the adoptee and their descendants and the adoptee's blood relatives cease. The only remaining effect of natural kinship is as an impediment to marriage.

In order to respect the child's right to an identity, Law 273/2004 stipulates in article 67 and develops in the following ones, that the adopters will gradually inform the child that he/she is adopted, starting at an early age, with the help of a specialist in the framework of the department of adoptions and post-adoptions within the service. Furthermore, adopters and adoptees are entitled to ask the competent authorities for extracts of public record documents, which attest to the date and place of birth, but does not reveal the identity of the natural parents or the adoption, aspects which we have already discussed widely in the section on adoption principles.

This is the general framework of the effects of adoptions, which can present the following subtleties:

- the partial extinctive effect if the adoptee is the natural of one of the spouses. This time, when the kinship is established through adoption between adoptee and adopter and his/her blood relatives, it only extinguishes the filiation to the natural parent that is not married to the adopter, as well as the blood relatives of the natural parent. However, there is no extinctive effect on the kinship between blood brothers adopted by the same adoptive parent or family.

- the constitutive effect is alone in the case of adopting the adopted child of the other spouse and the bonds of kinship thus created are added to those due to the effect of the previous adoption. Filiation and natural kinship of the same adoptee poses no interest, given that they ceased once the previous adoption has been granted $^{11}$.

Also, if the person in a relationship and living with the unmarried, single adoptive parent adopts the child, this produces similar effects to those of the successive adoption by the adoptive parent successively adopted by the person adoptive parent, single and unmarried, is

\footnotetext{
${ }^{10}$ Al. Bacaci, Viorica Dumitrache, Codrufa Hageanu, Dreptul familiei, C.H. Beck Publishing House, Bucharest 2012, p. 192.

${ }^{11}$ Emese Florian, Dreptul familiei, 3rd Edition, C.H. Beck Publishing House, Bucharest, 2010, pp. 592-593.
} 
in a stable relationship and living, and gives rise to similar effects subsequent adoption by foster parent spouse. Article 6 paragraph 3 from the Law on adoptions stipulates that the legal stipulations relating to the child's adoption by the spouse of the natural or adoptive parent, as well as the child's name, residence, rights and duties of parents and children, exercising parental authority, inheritance rights, identity papers for the child born out of wedlock with an established legal filiation to both parents are to be applied accordingly.

Adoptions do not produce any effect on the existing filiation between the adoptee and his/her descendants.

A second category of effects concerns the relationship between the adopter and the adoptee. In order to regulate these, article 471 from the Romanian Civil Code states that the adopter has the same rights and duties towards the adopted child as the natural parent, i.e. both those is concerning the person of the child and those concerning the child's property. In other words, exercising parental authority must only be undertaken by the adopter alone. The only exception to this rule is the situation where the adopter is the spouse of the natural parent, in which case the parental rights and duties shall be exercised jointly by the adopter and the natural parent, an exception which the current lawmaker is quick to make in article 471, paragraph 2 from the Romanian Civil Code.

The adoptee's rights and duties towards the adopter are the same as those of any person towards their natural parents. The adoptee, whether underage or of age, integrates the adoptive parent's family and enjoys the same legal status just as any blood descendant. It fits into his adoptive parent family like a natural descendant thereof, whether we are talking about minor adoptee or about the major and enjoy the same legal treatment provided natural offspring. Article 471 paragraph 3 from the Romanian Civil Code reiterates the principle of equal rights of children stipulated in article $260^{12}$.

If the adopter does not properly exercise his/her rights and duties, he/she may be deprived of parental rights. This penalty does not automatically lead to the dissolution of adoption, because it can be waived by the court. However, such a situation can lead to the dissolution of the adoption, in accordance with article 476 paragraph 2 from the Romanian Civil Code, in case the adoptee has to be protected under the law, if it is in the best interest of the underage adoptee.

In case both adoptive parents are sanctioned, the court may appoint a guardian or one of the safeguards provided by law and the child must be heard in the process.

After the adoption was granted, there are a number of consequences relating the name and residence of the adoptee who receives the name of the adopter. When the adopters are married or the adopter adopts their spouse's child and they have the same surname, the adopted child shall bear this name. If the adopters do not have the same surname and misunderstandings arise, the court will decide the name of the adoptee. Current legislation also stipulates the possibility of changing the surname of the underage adoptee, although not in the case of an adoptee of age with full legal capacity. This is possible when the adoptive parents request it, there are solid reasons and the 10-year old adoptee has consented to it. Subsequent to the adoption, the change of the adoptee's surname is only possible through administrative means, as stated by governmental ordinance 44/2003 on the name change through administrative means. If the adoptee is a married person bearing the same name as the other spouse, the adopted spouse may take the name of the adopter, but only with the consent of the spouse before the court granting the adoption. Regarding the home of the adoptee, if underage, will be home to the adopter or adoptive family. Article 92 from the Romanian Civil Code establishes the rule that the residence of the underage adoptee without full legal capacity will be the home of the parents or the home of the parent with a stable residence. If parents have different, separate homes and cannot agree on where the child will live, the court will

\footnotetext{
${ }^{12}$ Emese Florian, Noul Cod Civil. Comentariu pe articole (art. 1-2664), C.H. Beck Publishing House, Bucharest 2012, p. 513.
} 
decide taking into consideration the best interest of the child, as well as what the parents and the child have to say.

The adoption can also have effects on the nationality of the adoptee ${ }^{13}$. According to Law 21/1991 Romanian citizenship is acquired by a foreign citizen or stateless child if at least one of the adoptive spouses is a Romanian citizen or if there is only one adopter, he/she is a Romanian citizen. If only one of the adopters is a Romanian citizen, the citizenship of the adoptee will be decided jointly by the adopters, and if the adopters do not agree on the nationality of the adopted child, the decision will be taken by the court granting the adoption, taking into account the best interests of the child. If the child has turned 14 and his/her consent is required. If the child is under 14 but at least 10 years of age his/her opinion is compulsory and taken into consideration, depending on their age and maturity.

Last but not least, the effects of adoption are regulated by the Law on adoptions which includes a whole section in which the conditions and the way is informed on the adoption and the family of origin as well as the general juridical status of adoption information, starting from the principle of confidentiality of information on adoptions announced by the article 474 from the Romanian Civil Code.

\section{Conclusions}

The way in which our legislation regulates the effects of adoption is similar to the provisions sanctions in the European Convention of Strasbourg. In accordance with article 11 from the Convention, the adopted child becomes a full member of the family of the adopter(s) and has the same rights and obligation in relation to the relatives of the adopter(s) as the child of the adopter, whose parentage is legally established. The adopter(s) assumes parental responsibility for the child. The adoption ceases the legal relationship between child and father, mother and family of origin. Exceptionally, the official or unofficial spouse or partner of the adopter shall retain the rights and duties towards the adopted child if it is his/her child, unless the law stipulates otherwise. With regards to the termination of the legal relationship between the child and the family of origin, the Convention allows the contracting states to stipulate the exceptions to certain aspects such as the child's surname, impediments to marriage or common-law marriage.

\section{Bibliography}

D. Buzducea, F. Lazar, Anca Bejenaru, V. Grigoras, A. B. Panait, Ramona Popa, Strategii de comunicare despre adopție între părinți adoptivi şi copilul adoptat, "ROMPRINT SRL" Publishing House, Bucharest, 2013.

Al. Bacaci, Viorica Dumitrache, Codruța Hageanu, Dreptul familiei, "C.H Beck" Publishing House, Bucharest, 2012.

Fl. A. Baias, E. Chelaru, Rodica Constantinovici, I. Macovei, Noul Cod Civil. Comentariu pe articole (art. 1-2664), C.H. Beck Publishing House, Bucharest, 2012.

E. Ciongaru, Drept international privat, "Scrisul Romanesc" Publishing House, Craiova, 2011.

Emese Florian, Dreptul familiei, 3rd Edition, "C.H. Beck" Publishing House, Bucharest, 2010.

*** New Romanian Civil Code.

*** Law 273/2004 on the legal status of adoption, republished in 2012 in the Official Gazette of Romania, Part I, no. 259 from 19 April 2012.

*** The European Convention on the Adoption of Children, revised and ratified by Law 138/2011 published in the Official Gazette of Romania, Part I, no. 515 from 21 July 2011.

\footnotetext{
${ }^{13}$ E. Ciongaru, Drept international privat, Scrisul Romanesc Publishing House, Craiova, 2011, p. 32.
} 


\section{A. Drăghici}

*** Law 272/2004 on the protection and promotion of child rights published in the Official Gazette of Romania, Part I, no. 557 from 23 June 2004.

*** The International Convention on the Rights of the Child ratified by Romania through Law no.18/1990, published in the Official Gazette of Romania, Part I, no. 314 from 13 June 2001.

*** Convention on Protection of Children and Cooperation in international adoption, done concluded at the Hague on 29 May 1993 and ratified by Romania through Law 84/1994, published in Official Gazette of Romania, Part I, no. 298 from 21 October 1994, with subsequent amendments.

Other sources:

Brodzinsky, D.M., Schechter, M.D., Marantz Henig, R., A fi adoptat. Căutarea de o viață a sinelui, taken from the book Being Adopted: The Lifelong Search for Self available online at: www.adoptiiromania.ro. 